\title{
Policy on Restriction of Ownership of Land Rights to Prevent Land Abandonment
}

\author{
Mira Novana Ardani ${ }^{1}$, Gilang Muhammad Mumtaaz ${ }^{2}$ \\ \{miranovana@yahoo.com $\left.{ }^{1}\right\}$ \\ Universitas Diponegoro, Indonesia ${ }^{1,2}$
}

\begin{abstract}
The prohibition of ownership and control of land exceeding the limit is intended to avoid the concentration of ownership and control of land in certain groups. The problem of inequality in land ownership can lead to agrarian conflicts natural resource disparities, particularly gaps in tenure, perceptions and conceptions, as well as conflicting laws and policies. The problem is what is the policy to limit the ownership of land rights? and what is the relationship between limiting land rights ownership and preventing land abandonment? There is a policy to limit the ownership of land rights, but there is no concrete policy regarding the number of plots of land and the area of land that can be owned by a person or legal entity accompanied by strict sanctions. It is hoped that the restrictions on ownership of land rights that are more concrete and accompanied by strict sanctions can prevent the existence of abandoned land.
\end{abstract}

Keywords: Policy, Restriction of Ownership of Land Rights, Land

\section{Introduction}

Soil has an important role in life. Man from the moment he was born, until he returned to God did not escape the need for land. To support life, humans use land to be used as a place to live, an office, to be able to plant various types of plants, as a source of food production, to raise livestock, and many other benefits of land.

Given the importance of the land, of course it needs to be supported by rules that can regulate both the use of land, its use, who can own the land, how to own the land, and sanctions if there are violations of these rules. Of course, the provisions regarding the land are made with the purpose as stated in Article 33 (3) of the 1945 Constitution, namely that the earth, water and natural resources contained therein are controlled by the state and used for the greatest prosperity of the people.

Land is part of the scope of agrarian law, which when viewed from the meaning of the Basic Agrarian Law, agrarian law is not only a set of legal fields, each of which regulates control rights over certain natural resources. The group consists of [1]:

a. Land law, which regulates tenure rights over land, in the sense of the earth's surface;

b. Water law, which regulates tenure rights over water;

c. Mining law, which regulates control rights over excavated materials as intended by the Basic

Mining Law;

d. Fisheries law, which regulates control rights over natural resources contained in water; 
e. The law of control over energy and elements in outer space regulates the rights to control over energy and elements in outer space as referred to in Article 48 concerning Basic Agrarian Law.

The definition of agrarian includes earth, water, and the natural resources contained therein, within the limits as stipulated in Article 48 concerning Basic Agrarian Law, even covering outer space, namely the space above the earth and water containing energy and elements. Elements that can be used for efforts to maintain and develop the fertility of the earth, water and natural resources contained therein and other matters related to it [1]. The government's policy in managing agricultural is for justice and people's welfare.

The state, in this case the government as the highest authority organization of all Indonesian people, is given the authority to regulate, manage, utilize, and determine related agricultural. This is in accordance with the contents of Article 2 of Law Number 5 of 1960 concerning Basic Regulations on Agrarian Principles, namely that the right to control the state is given the authority to:

a. Regulate and administer the designation, use, supply and maintenance of the earth, water and space;

b. Determine and regulate legal relations between people and the earth, water and space;

c. Determine and regulate legal relations between people and legal actions concerning earth, water and space.

Implementation in carrying out its authority is used to achieve the greatest prosperity of the people in the sense of nationality, welfare and independence in an independent, sovereign, just and prosperous Indonesian society and legal state.

In order to carry out its authority, particularly in relation to land, the government must pay attention to the interests of all Indonesian people by upholding the principles for the welfare of all Indonesian people. Of course, the aspect of justice in arrangements related to land law cannot be ruled out.

In its implementation, the aspect of justice is not easy, so there are still problems that occur. Social justice is a universal problem when people feel oppressed. When people lose their land because it is revoked or released for state or private interests in arbitrary ways [2].

This is very closely related to the ownership and control of natural resources, namely land which has been the source of livelihood for most Indonesian people. The contributing factors include [2]:

a. Scarcity of land, namely the limited area of agricultural land which is relatively static, is expected with the need for land due to the increasing population.

b. There is a process of land loss (disland-owning process) that occurs due to the need for land for industry, both for factories and housing to reduce land for agriculture.

c. The process of land fragmentation is either due to the transfer of rights by sale and purchase or inheritance.

d. Swelling unemployment in agriculture has weakened the bargaining position of cultivators against land owners.

e. The concentration of land on a few people with a land area of hundreds of hectares, which in the end was not cultivated according to the purpose of acquisition, caused a lot of land to be abandoned.

These factors can lead to widening the gap between the rich and the poor. The economic crisis added to the suffering for them the peasants [2]. Inequality in land ownership can also occur, both from the subject of individual rights holders and legal entities.

The provisions in Article 7 of Law Number 5 of 1960 concerning Basic Regulations on Agrarian Principles also regulates the prohibition of ownership and control of land exceeding 
the limit, which is basically intended to avoid the occurrence of concentration of ownership and control of land in certain groups so as to harm other groups who have financial limitations to access land. The limited and constant nature of land and the value of land that is not limited to social, economic, political, and even religious causes a high potential for disparity in ownership and land tenure between capital owners and the weak economy [3].

Related to the problem of inequality in land ownership, it can lead to agrarian conflicts. natural resource disparities, particularly gaps in tenure, perceptions and conceptions, as well as conflicting laws and policies. Conflicts generally occur between individuals, between groups, communities and other parties, where each conflicting party seeks to be able to show its strength so that its interests can be realized properly, one of which is in the management and control of plantation land [4]. In addition, the policy regarding the limitation of ownership of land rights is closely related to preventing land abandonment.

This encourages the importance of conducting an academic study through a research entitled Policy for Restricting Land Rights Ownership to Prevent Land Abandonment. The problem that becomes the focus of discussion in this paper is how to limit the ownership of land rights? and what is the relationship between limiting land rights ownership and preventing land abandonment?

\section{Research Method}

In order to conduct legal research, a legal writing arrangement is needed based on a systematic, consistent method that aims to study the existing symptoms. The term method comes from the Greek methodos meaning a way or to, through a path. The method is a way or path that is passed by everyone in conducting research to understand the subject or object of research. Systematic means having a certain order, a structured activity, containing elements which are the points of thought and activity [5].

This legal research seeks to examine the policy of limiting ownership of land rights in order to prevent land abandonment using a normative juridical approach. The normative legal research method uses a normative juridical approach. The normative juridical approach is an approach that refers to the applicable laws and regulations [6].

The data analysis method is carried out by collecting data through the study of library materials or secondary data which includes primary legal materials, secondary legal materials and tertiary legal materials, both in the form of documents and applicable laws and regulations relating to the policy of limiting ownership of land rights for prevention. land abandonment. To analyze the legal material that has been collected, in this study using qualitative data analysis methods, namely normative juridical which is presented descriptively, namely by describing a policy related to the limitation of ownership of land rights in order to prevent land abandonment and then assessing whether the application is in accordance with the normative provisions.

\section{Theoretical Framework}

\subsection{Land Rights}

The scope of the earth according to the Basic Agrarian Law is the surface of the earth, and the body of the earth under it and under water. The surface of the earth as part of the earth is 
also called land. Land which is meant here does not regulate land in all its aspects, but only regulates one aspect, namely land in a juridical sense called land tenure rights. Land rights are part of land tenure rights [7]. Land rights are rights that give authority to use the surface of the earth or the land in question as well as the body of the earth and water and the space above it, only needed for purposes directly related to the use of the land, within the limits according to the law these and other higher laws [8].

The right of control over land contains a series of powers, obligations and or prohibitions for the holder of the right to do something about the land being entitled. Something that is allowed, obligated and prohibited to be done, which is the content of the right of control is what is the criteria or benchmark for distinguishing between the rights of control over land regulated in land law. For example, land rights, which are called property rights, in Article 20 of the Basic Agrarian Law, give the authority to use land that has been acquired indefinitely, while the right to cultivate and use the right to build is limited to the period of use of the land [1].

Land rights regulated in the Basic Agrarian Law primarily consist of building use rights, business use rights, property rights, and use rights. Article 9 paragraph 1 of the Basic Agrarian Law states that only Indonesian citizens can have a full relationship with the earth, water and space, within certain limits. Whereas in paragraph 2 it is stated that every Indonesian citizen, both male and female, has the same opportunity to obtain land rights and to obtain benefits and results, both for himself and his family.

\subsection{Abandoned Land}

The powers, obligations, and prohibitions of land rights holders should be obeyed. This is an effort in terms of maintaining the function of the soil, as well as soil fertility so that the land can still be used according to its function. The use of the land must of course pay attention to the social function of the land. The social function of land as regulated in Article 6 of the Basic Agrarian Law states that all land rights have a social function, which in the general explanation it is stated that any land rights that exist in a person cannot be justified, that the land will be used (or not used) solely for his personal interests, especially if it causes harm to the community.

In order to maintain the quality of the land and improve the welfare of the community, the rights holders, management rights holders, and basic land ownership holders are expected to be able to maintain their land and not neglect. Therefore, it is necessary to regulate the control and utilization of abandoned land. This is explained in Government Regulation Number 20 of 2021 concerning Control of Abandoned Areas and Lands. The state grants land rights to rights holders to be cultivated, used, and utilized and maintained properly. This is not only aimed at the welfare of the rights holders, but also for the welfare of the community, nation and state.

Based on the National Land Law as stated in the Basic Agrarian Law, land is abandoned if it is intentionally not used in accordance with the circumstances or the nature and purpose of the rights. The use of land by individuals or legal entities has the aim of achieving the welfare of the entire Indonesian people [9].

The legal consequences of land rights holders who do not carry out their obligations and do not use the land in accordance with their circumstances and the nature of their rights, all land rights will be erased and fall into the hands of the state, if viewed from the perspective of national land law, it is categorized as abandoned land and the termination of the relationship. law and affirmed as land controlled directly by the state [10]. 


\section{Results and Discussion}

\subsection{Policy to Restrict Ownership of Land Rights}

The concept of policy, epistemologically is defined as a series of concepts and principles that become the outline and basis of the plan for implementing a job, leadership, and way of acting (government, organization, and so on); a statement of ideals, goals, principles or intentions as a guideline for management to strive to achieve goals; guideline [11].

Policies are made by the government, then put into concrete actions, with the aim of serving the public interest, based on the public interest, based on applicable procedures and driven by the desire to avoid destructive conflicts. Policy is a means for the government to implement the provisions of higher laws and regulations. Government policies in implementing legislation can be stated in the form of government regulations, presidential regulations, ministerial regulations issued by the central government and in the form of regional regulations and regional head decisions made by regional governments. Policies in general are to implement legal provisions in carrying out the public interest [11].

The owner of a land right has the authority, rights, obligations, and prohibitions that must be obeyed. The general authority for the holder of land rights is to be able to use the land they are entitled to. The authority to use the land, the earth beneath it and the water and space above it. The body of the earth and water as well as the space in question does not belong to the holder of the right to the land concerned. He is only allowed to use it. Its use is only needed for interests that are directly related to the use of the land within the limits according to Law Number 5 of 1960 concerning Basic Agrarian Regulations and other higher regulations. The use of the earth's body must have a direct relationship with the building built on the land in question [1]. While the special authority can use the land according to its designation. For example, property rights can be used for all kinds of purposes for an unlimited time, as long as there is no special prohibition for that.

The land policy related to the limitation of ownership of land rights has been regulated in Law Number 5 of 1960. The policy is about the obligation for land owners to use their land and the obligations are general. This applies to all land rights, both property rights, building rights, business use rights and use rights. Obligations of a general nature contained in Law Number 5 of 1960 include [1]:

a. Article 6 of Law Number 5 of 1960 which states that all land rights have a social function;

b. Article 15 of Law Number 5 of 1960 concerning the obligation to maintain land that is appropriated;

c. Article 10 of Law Number 5 of 1960 specifically regarding agricultural land, namely the obligation for the party who owns it to work on or actively cultivate it themselves.

Based on the policy of limiting the ownership of land rights which is taken from the obligations of the holders of land rights, for the subject of rights holders, both individuals and legal entities, it is very difficult to carry out these obligations if they have an unlimited number of land parcels. The existence of rules regarding obligations for owners of land rights is certainly made so that the benefits of the land are maintained, its fertility is in accordance with its designation so that it can provide benefits not only for the owner, but also for the community. Regarding the regulation of obligations, prohibitions, and rights for holders of land rights, it has been regulated in Government Regulation Number 18 of 2021 concerning Management Rights, Land Rights, Flat Units, and Land Registration.

Other policies related to the limitation of ownership of land rights have been regulated in Article 7 of Law Number 5 of 1960 which regulates the prohibition of ownership and control of 
land exceeding the limit. This rule is one of the principles contained in agrarian law. Land ownership is not allowed to exceed the limit because it can harm the public interest. In the general explanation of Law Number 5 of 1960 (II number 7) it is stated that this provision needs to be accompanied by the provision of credit, seeds and other assistance with light conditions so that the owner will not be forced to work in other fields by giving up control of his land. to other people. There are no exceptions to this principle.

Furthermore, the policy of limiting ownership of land rights is contained in Article 17 of Law Number 5 of 1960. Article 17 is the implementation of Article 7 of Law Number 5 of 1960 which aims to ensure that land ownership does not accumulate in the hands of certain groups. It is regulated regarding the maximum and or minimum area of land that may be owned by one family or legal entity with rights. In his explanation, what is meant by a family is a husband, wife and children who are not married and are their dependents and whose number is around seven people.

In order to improve the standard of living of the farmers, they were given a large area of arable land. Law No. 56 Prp of 1960 ordered the government to make efforts so that every farmer and his family own a minimum of two hectares of agricultural land. According to his explanation, the two hectares of agricultural land can be in the form of rice fields, dry land, or rice fields and dry land. Efforts that must be carried out to achieve the minimum target of two hectares are mainly agricultural land expansion (extensification) with massive land clearing outside Java, followed by transmigration and industrialization. The determination of the minimum area does not mean that people who own less than two hectares of land will be required to relinquish their land. Two hectares is a goal that must be gradually achieved [1]. This rule only regulates agricultural land. While regarding the maximum area and amount of land for housing and other developments as well as the subsequent implementation of government regulations. This is explained in its Article 12.

Regarding the rules for limiting ownership of residential houses, it is stated in the Decree of the State Minister of Agrarian Affairs/Head of the National Land Agency Number 6 of 1998 concerning the Granting of Ownership Rights to Land for Residential Houses in Article 2, it is stated that in the application for registration of property rights, it is submitted to the Head of the Regency Land Office. The municipality, by attaching an attachment, is a statement from the applicant that with the acquisition of the property rights for which registration is requested, the person concerned will have ownership rights to land for residential homes of not more than 5 (five) plots which entirely covers an area of not more than 5,000 (five thousand) $\mathrm{m} 2$.

The policy to limit the ownership of existing land rights is deemed unable to accommodate the increasing demand for land at this time. To meet the needs of infrastructure development, housing development needs, houses, offices, and others. This can be seen from the still weak regulation of restrictions on housing, which is still in the form of a statement letter as an attachment which of course requires good faith from the person concerned. If these provisions are violated, there are no sanctions that regulate them.

As is the case with China, Since the last century, urbanization, the most significant force influencing land use and cover change, has become a worldwide socioeconomic phenomenon. In different stages of urbanization, due to the mismatch of land and socioeconomic resources, there are different forms of urban and rural land utilization [12].

The policy concepts behind the inequality of land tenure structures and giving birth to disputes over land and other natural resources must be changed towards the concept of peopleoriented policies, promoting justice, being integrative, sustainable and sustainable in their management. Such a concept is of course still very abstract and should be followed by a more 
practical form, which in real circumstances cannot be separated from interaction with concepts in other fields such as politics, economics and socio-culture which influence each other [2].

The existing regulations only cover the boundaries intended for agricultural land. And even then the rules since 1960 that need to be adapted to current conditions and circumstances. Likewise, the rules and enforcement of sanctions have not been enforced firmly.

Types of primary land rights, including property rights, building rights, use rights, and use rights, of course, really need existing rules regarding the limitation of ownership of each of these rights and also pay attention to who is the subject who needs the land, whether he is an individual. or legal entity. If it is an individual, of course, the name that appears on the proof of ownership of land rights in the form of a certificate directly points to the owner, so that it can be adjusted how many limitations of land rights he can have. Meanwhile, if the need for the land is a legal entity, in which the legal entity has capital, it can be considered in granting restrictions on the ownership of a land right.

Policies to limit the ownership of land rights are needed. taking into account the three basic values that function as a guide and reference in the formation and implementation of law, which include [13]:

a. Legal certainty

Legal certainty is defined as the existence of clear behavioral scenarios that are general in nature and binding on all members of the community, including the legal consequences. Legal certainty in relation to policies to limit ownership of land rights can be seen from certificates as proof of ownership of land rights which already contain physical data and juridical data on the land in question. if there are clear and firm rules regarding land ownership restrictions. The case for a link between aggregate insecurity and the individual's decision to invest has rested on household-level studies of the security of land tenure. Since land is often central to a poor household's livelihood, this literature has argued that insecure tenure distorts a wide range of household decisions [14].

b. Basic values of justice

Justice is an abstract concept that is not so easy to concretize in a formula that can provide an overview of the essence. Satjipto identified nine definitions of justice, including: giving to everyone what should be received, giving to everyone who according to the rule of law is his right, virtue to give results that have become his share, giving something that can satisfy people's needs, personal equality, giving independence to individuals to pursue their prosperity, to provide opportunities for everyone to seek the truth, and to give something worthy.

The basic value of justice is very important in formulating and forming policies to limit ownership of land rights. It is hoped that there will be no gaps among the community in the ownership of land rights. In its formulation, it can be noted not only the limit on the number of parcels that can be owned by a person or legal entity, but also the limit on the total area of land owned by a person or legal entity.

c. Benefit value

The value of expediency is optimizing the achievement of social goals from the law. Every legal provision in addition to being intended to realize order and order as the ultimate goal, also has certain social goals, namely the interests that are desired to be realized through law, both those originating from individuals as well as society and the state.

The value of benefit is of course very in line with the principles contained in the principles contained in agrarian law, especially land law. That land has a social function, in which land in its use must be adapted to the nature of its rights. In addition, in its use it must be useful and prevent its damage. 


\subsection{The Relationship Between Restriction of Ownership of Land Rights and Prevention of Land Abandonment}

The occurrence of abandoned land cannot be separated from the granting of land rights by the state to individuals or legal entities, with the aim of being used or cultivated in order to achieve prosperity or achieve people's welfare. The use of the land must be in accordance with the circumstances, nature and purpose of the rights [9].

With the use and ownership of a land right that has not been regulated, there will be the potential for abandoned land to occur. If a person or legal entity owns land which has a very large number of plots and is located in several areas in Indonesia, then the utilization and use may not be in accordance with its function, so that it can cause the land to be damaged.

Policies related to the use of land that are appropriate and not in accordance with the nature and purpose of the rights have been set forth in Article 10 paragraph (1), Article 6, Article 15 of Law Number 5 of 1960. Maintaining land, including increasing its fertility and preventing damage is an obligation. any person, legal entity or agency that has a legal relationship with the land, taking into account the economically weak party. In the provisions of Article 15 there are legal principles or principles of propriety and social justice. As for carrying out obligations must be good and right. The law requires good faith in carrying out obligations between people who have a relationship with the land on the one hand (the relationship of the subject and object of the right) as well as the relationship between the subject of the right (recipient) and the subject (giver). If this is ignored, then the holder of land rights can be given a sanction of revocation of rights because they have violated the requirements or have done actions that make the land neglected [9]. This also underlies the importance of reviewing the area of land owned and its use which is faced with inequality in land tenure in Indonesia.

Inequality of land tenure is one of the strategic issues in the land sector, inequality in ownership, control, use, and utilization of land which is characterized by a small number of people controlling most of the land and conversely most people only controlling a small area of land. On the other hand, the condition of ownership of very large assets is not commensurate with the ability to manage them, because not all land rights that have been granted are managed properly by the right holders, resulting in a lot of land being abandoned. Land has lost its economic and social functions, there have also been prolonged conflicts in areas that have been designated as abandoned lands [10].

The definition of abandoned land according to Government Regulation Number 20 of 2021 concerning Control of Areas and Abandoned Land, namely land rights, land with management rights, and land obtained on the basis of control over land, which is intentionally not cultivated, not used, not utilized, and or not maintained .

The object of controlling abandoned land is contained in article 7 of them, including land ownership rights, building rights rights, business use rights, use rights, management rights, and land obtained on the basis of land tenure. Before a land is determined to be abandoned land, it has been designated as abandoned indicated land, then from the data indicated abandoned land is followed up with the control of abandoned land through evaluation stages of abandoned land, abandoned land warning, and determination of abandoned land. This is the content of Article 22.

In addition, the relationship between restrictions on ownership of land rights and prevention of land abandonment can be found in the explanation of Government Regulation Number 20 of 2021, in order to maintain land quality and improve the welfare of the community, rights holders, management rights holders, and basic land tenure holders. is expected to be able to maintain and maintain the land and not neglect. In today's reality, neglect of land is increasingly 
causing social, economic, and people's welfare disparities and reducing environmental quality. Abandonment of land also has an impact on the inhibition of the achievement of various development program objectives, vulnerability to food security, and national economic resilience and the closure of socio-economic access of the community, especially farmers to land.

A person or legal entity has the right to land to be cultivated, used, and utilized and maintained properly. In accordance with the explanation of Government Regulation Number 20 of 2021, in the event that the right holder abandons his land, Law Number 5 of 1960 has regulated the legal consequences, namely the abolition of the rights to the land in question and the termination of legal relations and affirmed as land controlled directly by the state. So that if there is a policy regarding the limitation of ownership of land rights that is more concrete and accompanied by strict sanctions, it is hoped that abandoned land will be prevented.

\section{Conclusion}

The policy to limit the ownership of existing land rights is deemed unable to accommodate the increasing demand for land at this time. The existing regulations only cover the boundaries intended for agricultural land. And even then the rules since 1960 that need to be adapted to current conditions and circumstances. Likewise, the rules and enforcement of sanctions have not been enforced firmly.

The relationship between restrictions on ownership of land rights and prevention of land abandonment is that if there is a policy regarding restrictions on land rights ownership that is more concrete and accompanied by strict sanctions, it is hoped that abandoned land will be prevented.

\section{Acknowledgements}

This research was supported by Faculty of Law, Universitas Diponegoro. We thank our colleagues from private law of Faculty of Law, Universitas Diponegoro who provided insight and expertise that greatly assisted the research.

\section{References}

[1] B. Harsono, "Hukum Agraria Indonesia, Sejarah Pembentukan Undang-undang Pokok Agraria, Isi dan Pelaksanaannya, Jilid 1: Hukum Tanah Nasional," Djambatan, Jakarta, 2008.

[2] A. Sodiki, M. Huda, N. R. Ana, and M. M. Ali, Politik hukum agraria. Konstitusi Press (Konpress), 2013.

[3] S. Rongiyati, "Land Reform Melalui Penetapan Luas Tanah Pertanian (Kajian Yuridis Terhadap UU No. 56/PRP/ Tahun 1960 Tentang Penetapan Luas Tanah Pertanian)," Negara Huk. Membangun Huk. untuk Keadilan dan Kesejaht., vol. 4, no. 1, pp. 1-15, 2016.

[4] M. P. Suharto and G. K. Basar, "Konflik Agraria Dalam Pengelolaan Tanah Perkebunan Pada PT Hevea Indonesia (PT Hevindo) Dengan Masyarakat Kecamatan Nanggung Kabupaten Bogor," J. Kolaborasi Resolusi Konflik, vol. 1, no. 1, pp. 55-64, 2019.

[5] G. Suteki \& Taufani, "Metodologi penelitian hukum (filsafat, teori dan praktik)," Depok PT RajaGrafindo Persada, 2018. 
[6] B. Sunggono, "Metodologi Penelitian Hukum (Suatu Pengantar), Jakarta: PT," Raja Graf. Persada, 2003.

[7] U. Santoso, "Hukum Agraria," Kaji. Komprehensif, Kencana, Jakarta, 2012.

[8] S. Ismaya, "Pengantar hukum agraria," Yogyakarta Graha Ilmu, 2011.

[9] Suhariningsih, "Tanah Terlantar: Asas dan Pembaharuan Konsep Menuju Penertiban,” Jakarta Prestasi Pustaka Publ., 2009.

[10] D. A. Mujiburohman and E. Soetarto, "Penegakan Hukum Penertiban dan Pendayagunaan Tanah Terlantar." Yogyakarta: STPN Press, 2019.

[11] S. H. Arba and M. HUM, Hukum Tata Ruang dan Tata Guna Tanah. Sinar Grafika, 2019.

[12] Z. Tao, J. Guanghui, L. Guangyong, Z. Dingyang, and Q. Yanbo, "Neglected idle rural residential land (IRRL) in metropolitan suburbs: Spatial differentiation and influencing factors," J. Rural Stud., vol. 78, pp. 163-175, 2020.

[13] N. Ismail, "Perkembangan hukum pertanahan Indonesia:: Suatu pendekatan ekonomi-politik." Universitas Gadjah Mada, 2006.

[14] H. Huntington and A. Shenoy, "Does insecure land tenure deter investment? Evidence from a randomized controlled trial," J. Dev. Econ., vol. 150, p. 102632, 2021. 